\title{
Degradation of 4-Chlorophenol in a Batch Electrochemical Reactor Using BDD Electrodes
}

\author{
Ever Peralta, , Martín Ruíz ${ }^{1}$, Gerardo Martínez ${ }^{1}$, Juan Mentado-Morales ${ }^{1}$, Luis G. Zárate ${ }^{2}$, \\ Mario E. Cordero ${ }^{2}$, Marco A. Garcia-Morales ${ }^{3}$, Reyna Natividad ${ }^{4}$ and Alejandro Regalado-Méndez, ${ }^{1, *}$ \\ ${ }^{1}$ Universidad del Mar, Campus Puerto Ángel, Ciudad Universitaria S/N, Puerto Ángel, Oaxaca, \\ México, C. P.70902 \\ ${ }^{2}$ Universidad Popular Autónoma del Estado de Puebla, Puebla, México, C.P. 72410 \\ ${ }^{3}$ Universidad Autónoma del Estado de México, Facultad de Ciencias, Campus el Cerrillo, Carretera \\ Toluca - Ixtlahuaca Kilómetro 15.5, Edo. de México, C.P. 50200 \\ ${ }^{4}$ Centro Conjunto de Investigación en Química Sustentable CCIQS, UAEM-UNAM, Facultad de \\ Química, Universidad Autónoma del Estado de México, UAEMex Carretera Toluca-Atlacomulco, km \\ 14.5, C.P. 50200 Toluca, Mexico. \\ *E-mail: pere@ angel.umar.mx, alejandro.regalado33@gmail.com
}

Received: 20 December 2017 / Accepted: 23 February 2018 / Published: 10 April 2018

The influence of current density $(j)\left(0.25,0.30,0.25\right.$ and $\left.0.40 \mathrm{~A} / \mathrm{cm}^{2}\right)$, initial $\mathrm{pH}(2.6,6.5$ and 12), stirring speed (As) $(400,500$ and $600 \mathrm{rpm})$, and initial concentration of 4-chlorophenol ([4-CP $\left.]_{0}\right)(300$, 500 and $700 \mathrm{mg} / \mathrm{L}$ ) on degradation of persistent pollutant in a batch electrochemical cell without divisions is presented in this paper. The electrochemical cell was composed of two boron-doped diamond electrodes (BDD). The results of the study showed that best conditions for total degradation of 4-CP were: $j$ of $0.40 \mathrm{~A} / \mathrm{cm}^{2}$, initial $\mathrm{pH}$ of 6.5 , As of $500 \mathrm{rpm}$, and $[4-\mathrm{CP}]_{0}$ of $500 \mathrm{mg} / \mathrm{L}$, after 150 min of reaction time. Removal of total organic carbon (TOC) was $83 \%$ at these conditions. The byproducts were identified by UHPLC. This allowed for the proposal of a degradation pathway of 4-CP at the best conditions. Furthermore, these results demonstrate that the electrochemical method employed in this study allows high percentages (96\%) of degradation of 4-CP and that the process is applicable to wastewater treatment.

Keywords: Boron-doped diamond electrode; 4-Chlorophenol; Electrochemical cell; Electrochemical degradation.

\section{INTRODUCTION}

4-Chorophenol (4-CP), an EPA listed and high-priority air and water pollutant [1], is commonly used in dye and drug synthesis and in cosmetic, paper, and other industries. 4-CP is currently removed in discharged wastewaters from those sources. Because the degradation of this 
compound is very difficult by natural means, it tends to persist in the environment, so it is currently found in surface and ground waters [2]. There are three main methods suitable for elimination of toxic and persistent phenolic compounds: adsorption, biological and advanced oxidation [3, 4]. Of these, the advanced oxidation method, specifically electrochemical degradation, is the most efficient, as the degree of mineralization that can be reached is usually high. Moreover, when compared with other methods, it does not require or generate toxic chemicals, in accordance with one of the principles of green chemistry, and it is also capable of working at room temperature and pressure, which makes this method highly suitable for degradation of recalcitrant compounds [5]. For these reasons, electrochemical process could be an attractive method for wastewater treatment when the limits of discharge, high volumes of wastewater, and high treatment cost become an issue $[6,7]$. To achieve the complete oxidation of the target compound the right electrodes and the best operating conditions must be chosen [2, 8-18]. Several investigations have shown higher degrees of mineralization of organic compounds when BDD electrodes rather than DSA electrodes are used [19] because high amounts of hydroxyl radicals are produced from oxidation of water molecules, which brings a very high oxidative potential to this type of electrode [6].

BDD electrodes have been used as anodes to degrade several recalcitrant compounds such as cyanides, drugs, phenols, chlorophenols, nitrophenols, cresols, naphthol, polyhydroxibenzenes, polyacrylates, surfactants and pigments $[6,20,21]$. BDD electrodes acting as anodes have also been used to oxidize 4-CP using cathodes of different materials. Thus, in [9] a total mineralization of 4-CP was achieved. Additionally, in [10] low values of biochemical oxygen demand (BOD) were obtained from an initial 4-CP concentration of $500 \mathrm{ppm}$. Both authors have been using the electrochemical degradation method.

Other researchers have used two BDD electrodes both as anodes and cathodes in cells without division to produce $\mathrm{H}_{2} \mathrm{O}_{2}$ from $\mathrm{O}_{2}$ reduction in the cathode [22-25] and to eliminate pollutants in wastewaters [26]. The same types of electrodes have also been used in divided cells to produce $\mathrm{H}_{2} \mathrm{O}_{2}$ in the cathodic section to degrade phenol in the anodic section by the action of $\bullet \mathrm{OH}$ radicals [27].

This research focused on electrochemical degradation of 4-CP in a cell batch without division by using two BDD electrodes and a solution of $\mathrm{Na}_{2} \mathrm{SO}_{4} 0.1 \mathrm{M}$ as supporting electrolyte at different operation conditions.

\section{MATERIALS AND METHODS}

\subsection{Reagents}

Standard solutions were prepared using distilled water: 4-chlorophenol (500 mg/L) (from 4-CP 98\% purity Merck), $0.1 \mathrm{M} \mathrm{Na}_{2} \mathrm{SO}_{4}$ (from $\mathrm{Na}_{2} \mathrm{SO}_{4} 99 \%$ purity Fluka), $0.1 \mathrm{M} \mathrm{NaOH}$ (from $\mathrm{NaOH} 97 \%$ purity Meyer) and $0.1 \mathrm{M} \mathrm{HCl}$ (from hydrochloric acid 36.5\% concentration Meyer). 


\subsection{Degradation of 4-CP}

$400 \mathrm{~mL}$ of a synthetic solution containing $500 \mathrm{mg} / \mathrm{L}$ of $4-\mathrm{CP}$ in $\mathrm{Na}_{2} \mathrm{SO}_{4} 0.1 \mathrm{M}$ was added to a $500 \mathrm{~mL}$ electrolysis cell without division equipped with two identical BDD electrodes (Metaken ${ }^{\mathrm{TM}}$ ) with a geometric area of $10 \mathrm{~cm}^{2}$, separated by a distance of $2 \mathrm{~cm}$. Several tests were performed under the following operating conditions: $j=0.25,0.30,0.35$ and $0.40 \mathrm{~A} / \mathrm{cm}^{2}$; initial $\mathrm{pH}$ values $=2.6,6.5$ and $12 ; A_{s}=400,500$ and $600 \mathrm{rpm}$, and $[4-\mathrm{CP}]_{0}=300,500$ and $700 \mathrm{mg} / \mathrm{L}$. All tests were done at $25^{\circ} \mathrm{C}$. Reaction time was 150 min. Energy was supplied by a Gwinstek GW GPR-351OHD single output DC power supply and $\mathrm{pH}$ was monitored with a Hanna HI2210 potentiometer. Samples of solution were taken every $30 \mathrm{~min}$ for UV analysis in a UV/VIS Beckman DUß 330 spectrophotometer at a wavelength of $290 \mathrm{~nm}$ in order to follow degradation of 4-CP. 4-CP concentration was obtained by using a calibration curve that was constructed from absorbance values of several standard solutions of 4-CP (i.e., 25, 50, 100, 200, 300, 400 and $500 \mathrm{mg} / \mathrm{L}$ ). The degradation efficiency was calculated by [24]:

Degradation efficiency $\%=\frac{[\mathrm{C}]_{0}-[\mathrm{C}]_{\mathrm{t}}}{[\mathrm{C}]_{0}} \times 100$

where $[\mathrm{C}]_{0}$ is the initial concentration, and $[\mathrm{C}]_{\mathrm{t}}$ is the concentration at time $\mathrm{t}$.

Degradation of 4-CP is carried out by $\bullet \mathrm{OH}$ radicals that are formed according to the following reaction [28],

$$
\mathrm{BDD}+\mathrm{H}_{2} \mathrm{O} \rightarrow \mathrm{BDD}(\cdot \mathrm{OH})+\mathrm{H}^{+}+\mathrm{e}^{-}
$$

\subsection{Determination of byproducts and remaining products}

The identification of by-products and remaining products from degradation of 4-CP was performed by ultra high-performance liquid chromatography (UHPLC, Thermo Scientific Vanquish model) equipped with a DAD and UV-Vis detector using a Waters 616 Quaternary Pump. The data analysis employed Chromeleon 7.2 software. The identification and quantification of organic acid and aromatic compounds by UHPLC followed the methodology proposed in [3].

\subsection{TOC Measurement}

Total organic carbon (TOC) was measured in solutions at different reaction times during the electrolysis in a 6001 Shimadzu TOC analyzer. The percentage of mineralization current efficiency (\% MCE) was computed from TOC data by using the following equation [29, 30],

$$
\operatorname{MCE}(\%)=\frac{\mathrm{nFV}_{\mathrm{s}}(\mathrm{TOC})_{\text {Exp }}}{4.32 \times 10^{7} \mathrm{mIt}} 100
$$

where $F$ is the Faraday constant $(96,487 \mathrm{C} / \mathrm{mol}), V_{s}$ is the solution volume $(\mathrm{L}), \Delta(\mathrm{TOC})_{\operatorname{Exp}}$ is the decline of experimental TOC value during electrolysis $(\mathrm{mg} / \mathrm{L}), 4.32 \times 10^{7} \mathrm{mg} \cdot \mathrm{s} / \mathrm{mol} \cdot \mathrm{h}$ is a conversion factor, $m$ is the number of carbon atoms, $I$ is the applied current (A), $n$ is the number of electrons, and $t$ is the electrolysis time (h). 
The number of electrons was determined by considering the following oxidation reaction of 4$\mathrm{CP}$ to $\mathrm{CO}_{2}$ and inorganic ions [3]:

$$
\mathrm{C}_{6} \mathrm{H}_{5} \mathrm{OCl}+11 \mathrm{H}_{2} \mathrm{O} \rightarrow 6 \mathrm{CO}_{2}+\mathrm{Cl}^{-}+27 \mathrm{H}^{+}+26 \mathrm{e}^{-}
$$

Specific energy consumption per mass unit of TOC $\left(\mathrm{EC}_{\mathrm{TOC}}\right)$ was calculated by using equation (5) (according to [31]),

$$
\mathrm{EC}\left(\frac{\mathrm{kWh}}{\mathrm{g} \text { TOC }}\right)=\frac{\mathrm{E}_{\text {Cell }} \mathrm{It}}{\mathrm{V}_{\mathrm{s}} \Delta(\mathrm{TOC})_{\operatorname{Exp}}}
$$

where $E_{\text {cell }}$ is the mean cell voltage $(\mathrm{V}), V_{s}$ is the synthetic solution volume (L), $\Delta(\mathrm{TOC})_{\operatorname{Exp}}$ is the decline of experimental TOC value during the electrolysis $(\mathrm{mg} / \mathrm{L}), I$ is the applied current (A), and $t$ is the electrolysis time (h).

\section{RESULTS AND DISCUSSION}

\subsection{Degradation of 4-CP}

\subsubsection{Effect of the current density $(j)$}

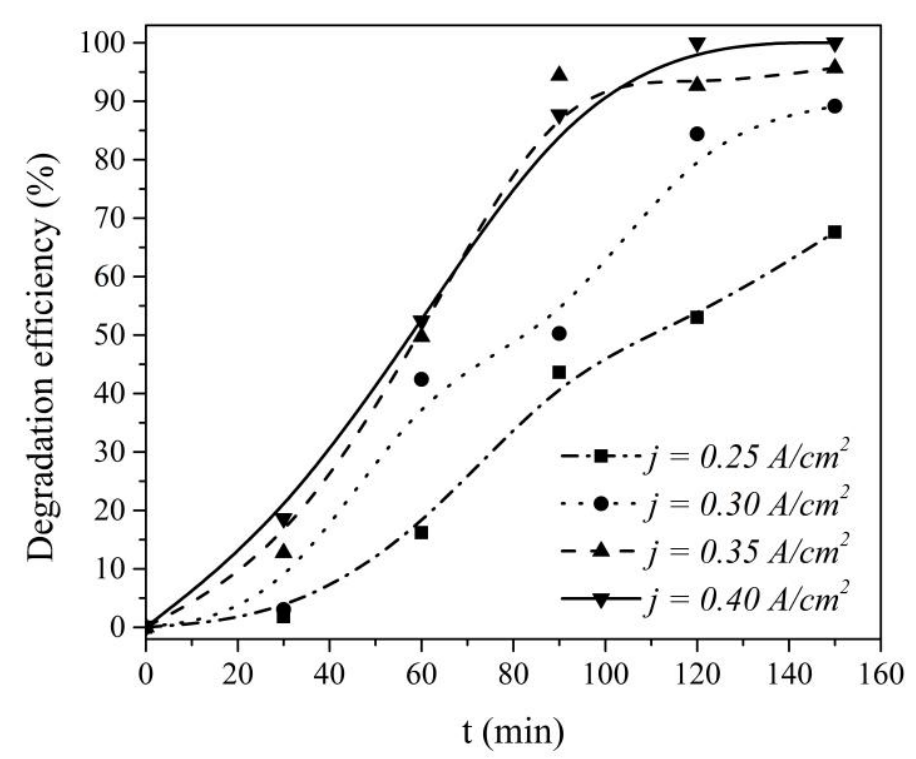

Figure 1. Effect of current density on $4-\mathrm{CP}$ concentration profiles. $[4-\mathrm{CP}]_{0}=500 \mathrm{mg} / \mathrm{L}, \mathrm{As}=500 \mathrm{rpm}$, and $\mathrm{pH}=6.5$.

The effect of current density on the degradation efficiency of 4-CP was studied at $0.25,0.30$, 0.35 and $0.40 \mathrm{~A} / \mathrm{cm}^{2}$. Fig. 1 shows that the degradation efficiency percentage of 4-CP increases asymptotically and the degradation rate of 4-CP is high when the applied current density is high. After 150 min of electrolysis, the degradation efficiency of 4-CP reached $67.6 \%, 89.2 \%, 95.7 \%$ and $100 \%$ at current densities of $0.25,0.30,0.35$ and $0.40 \mathrm{~A} / \mathrm{cm}^{2}$, respectively. These results suggests that to 
achieve the highest organic load degradation high current densities must be used, in agreement with [32].

This confirms that increasing current density yields higher concentrations of $\bullet \mathrm{OH}$ produced by the BDD anodes and more 4-CP is oxidized by $\bullet \mathrm{OH}[33]$.

Results indicated that the best $j$ to remove $4-\mathrm{CP}$ is $0.40 \mathrm{~A} / \mathrm{cm}^{2}$. Therefore, at this $j$ the effects of the three variables $\mathrm{pH}, A_{s}$, and $[4-\mathrm{CP}]_{0}$ were studied.

\subsubsection{Effect of initial $p H$}

The effect of initial $\mathrm{pH}$ on the degradation efficiency of 4-CP was studied at three different $\mathrm{pH}$ values (2.6, 6.5 and 12) because the $\mathrm{pH}$ of the synthetic solution could influence significantly the electrochemical degradation of 4-CP. Fig. 2 shows the effect of initial $\mathrm{pH}$ on the degradation efficiency versus electrolysis time. The synthetic solution of 4-CP was completely eliminated after 150 min of treatment at $\mathrm{pH} 2.6$ and 6.5 , while $96 \%$ was eliminated at $\mathrm{pH}$ of 12 .

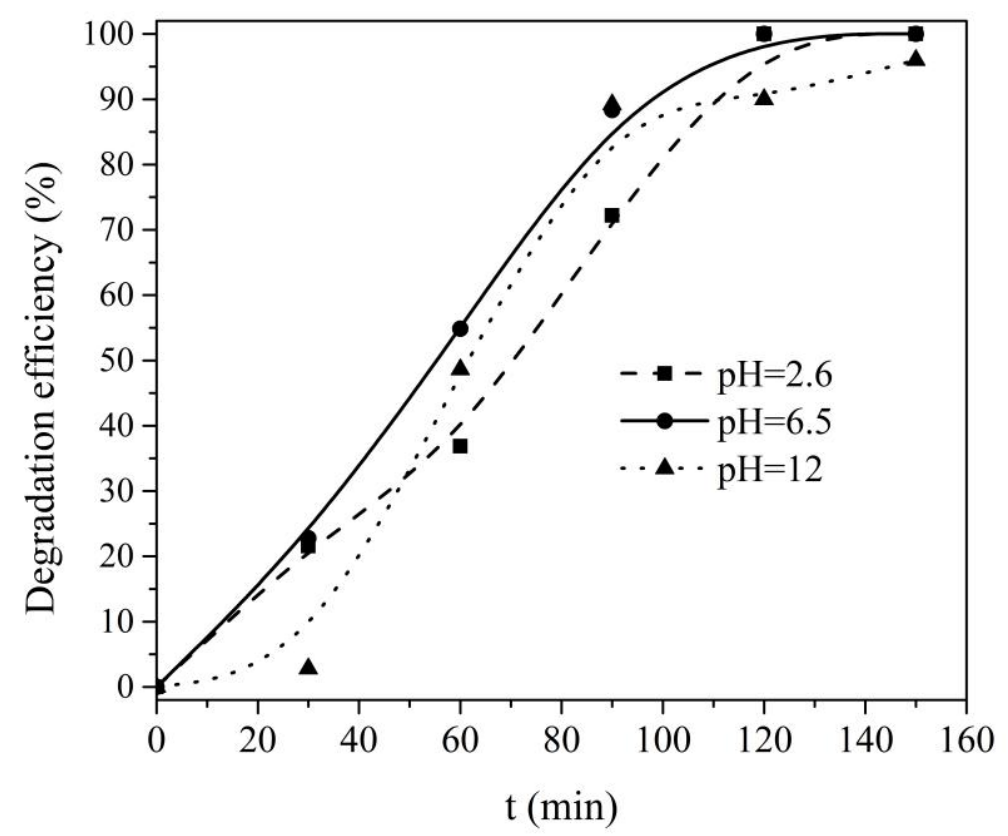

Figure 2. Degradation profiles of $4-\mathrm{CP}$ at different $\mathrm{pH}$ values. $[4-\mathrm{CP}]_{0}=500 \mathrm{mg} / \mathrm{L}, \mathrm{As}=500 \mathrm{rpm}$, and $\mathrm{j}=0.40 \mathrm{~A} / \mathrm{cm}^{2}$.

Results show that the degradation of 4-CP was not influenced by the initial $\mathrm{pH}$. To this point the $\mathrm{pH}$ did not need to be fixed, and in this study the $\mathrm{pH}$ of the synthetic solutions was 6.5. At this point of the investigation, the best experimental condition was $\mathrm{pH}=6.5$ and a current density of 0.40 $\mathrm{A} / \mathrm{cm}^{2}$. For this reason the next experiment was carried out at those experimental conditions. 


\subsubsection{Effect of stirring speed (rpm)}

The influence of stirring speed $\left(\mathrm{A}_{\mathrm{s}}\right)(\mathrm{rpm})$ on the decrease of 4-CP concentration is shown in Fig. 3 with a $j$ of $0.40 \mathrm{~A} / \mathrm{cm}^{2}$ and a pH of 6.5. A sharp decline in 4-CP concentration at 400, 500 and $600 \mathrm{rpm}$ can be observed, and total degradation of 4-CP is accomplished at $150 \mathrm{~min}$, which demonstrates that an increase in the value of stirring speed does not necessarily lead to an increase in degradation efficiency. This unexpected behavior might be explained by a complex reaction mechanism of the 4-CP degradation, the use of a electrochemical cell without division, and reduction reactions at the cathode [34].

So far, it has been observed that stirring speed does not have an important effect on the electrolysis of 4-CP, as high removal efficiencies of 4-CP are already known [3].

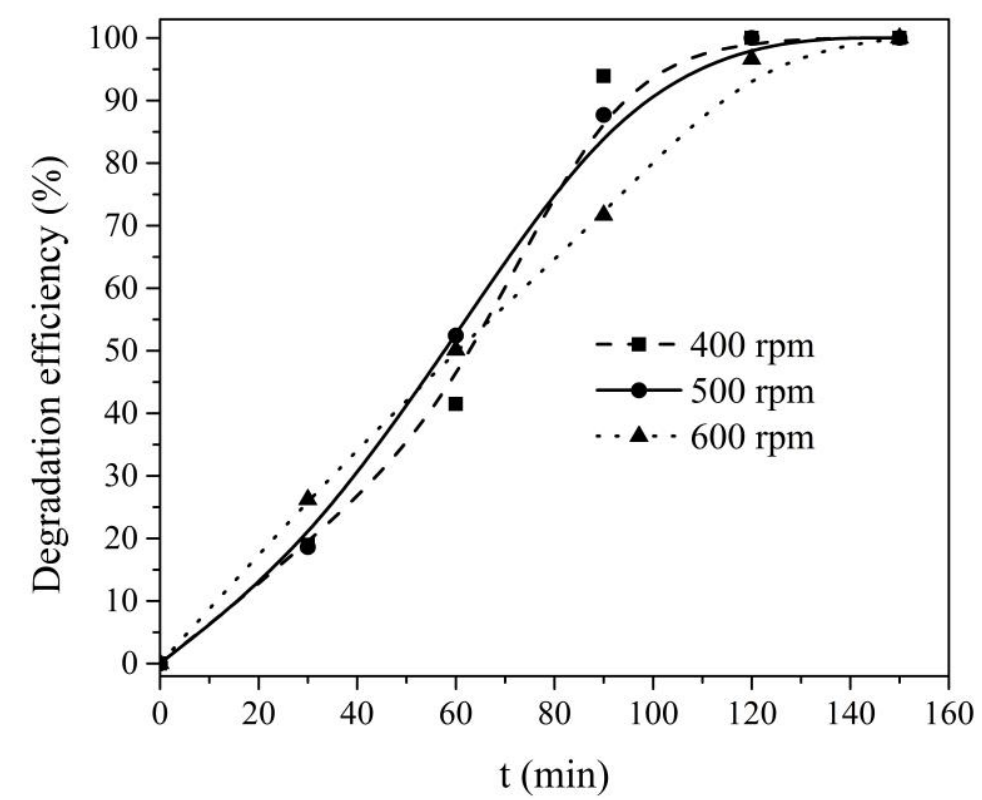

Figure 3. Degradation profiles of $4-\mathrm{CP}$ at different values of $\mathrm{As},[4-\mathrm{CP}]_{0}=500 \mathrm{mg} / \mathrm{L}, \mathrm{pH}=6.5$, and $\mathrm{j}=0.40 \mathrm{~A} / \mathrm{cm}^{2}$.

\subsubsection{Effect of the $[4-C P]_{0}$}

The effect of $[4-\mathrm{CP}]_{0}$ on the electrochemical degradation was investigated at three different [4$\mathrm{CP}]_{0}(300,500$, and $700 \mathrm{mg} / \mathrm{L})$. Conditions during electrolysis were: $\mathrm{pH}$ of $6.5, j$ of $0.40 \mathrm{~A} / \mathrm{cm}^{2}$ and $A_{s}$ of $500 \mathrm{rpm}$. Fig. 4 shows that the total removal of 4-CP was reached at $150 \mathrm{~min}$ independently of initial 4-CP concentrations. This suggests that under best operation conditions, the degradation of 4-CP is carried out by mass transport, which is in accord with [9]. 


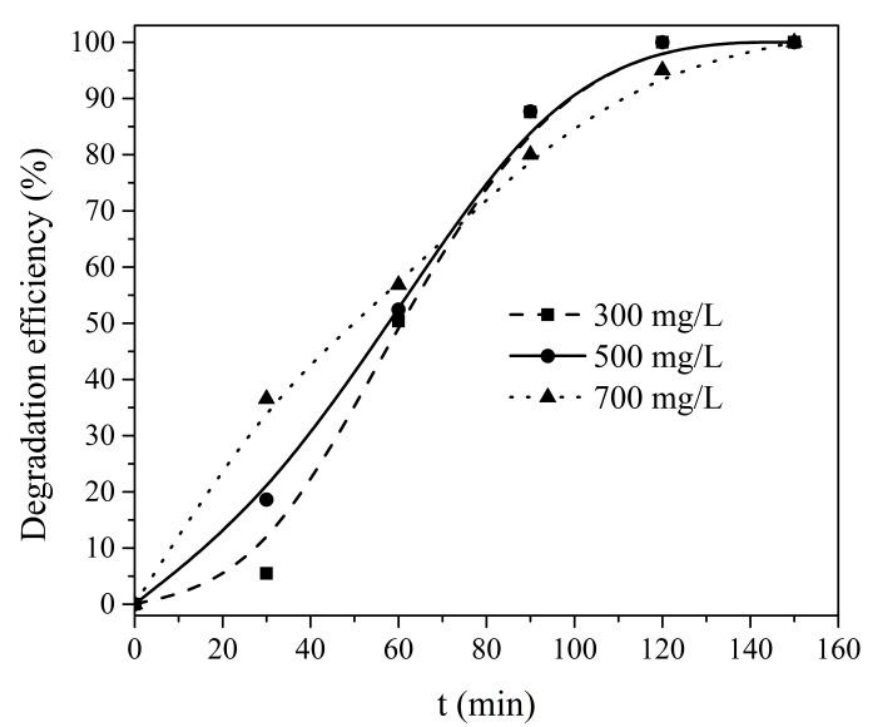

Figure 4. Effect of initial 4-chlorophenol concentration $[4-\mathrm{CP}]_{0}$, at $\mathrm{pH}=6.5$, As $=500 \mathrm{rpm}$, and $\mathrm{j}=0.40 \mathrm{~A} / \mathrm{cm}^{2}$.

\subsubsection{Reaction pathway of 4-CP}

UHPLC analysis was employed to propose a reaction pathway of degradation of 4-CP under the best operating conditions. All by-products were identified unequivocally by comparing their retention time with the ones from standard compounds.

4-CP: 4-chlorophenol; 4-CC: 4-chlorocatechol; CC: Catechol; $\mathrm{BQ}$ : Benzoquinone; Ph: Phenol; $\mathrm{HQ}$ : Hydroquinone

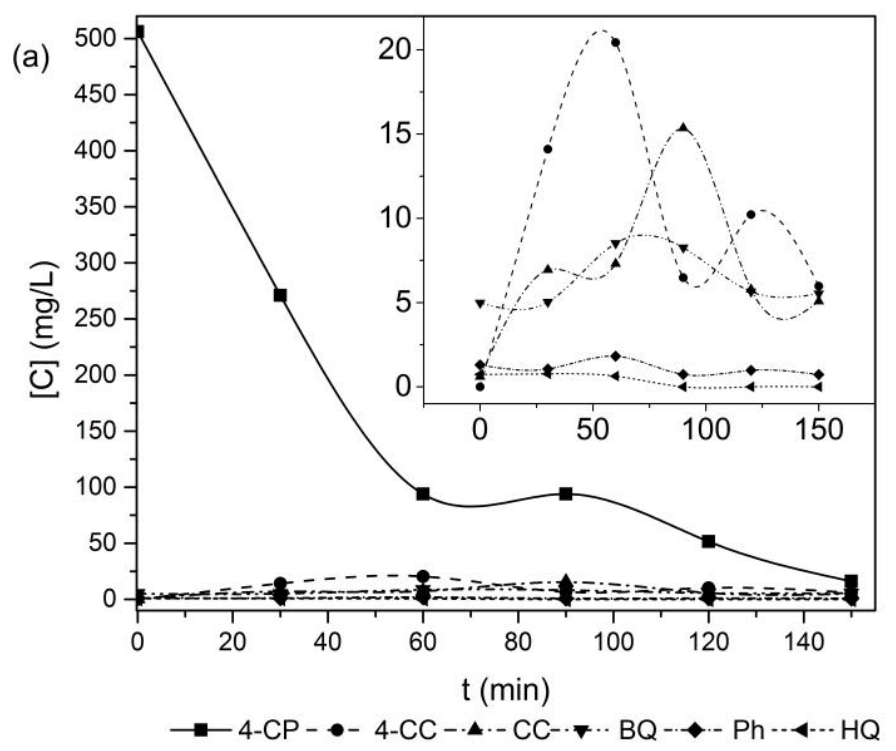




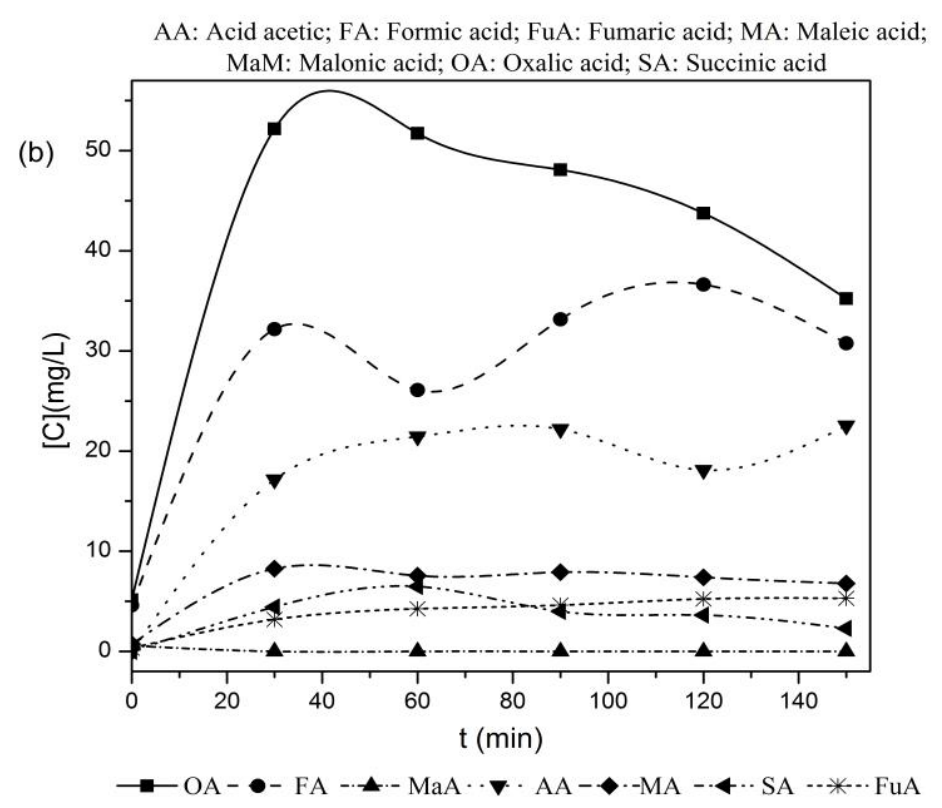

Figure 5. Concentrations of 4-CP, organic acids and aromatic compounds versus electrolysis time at $[4-\mathrm{CP}]_{0}=500 \mathrm{mg} / \mathrm{L}, \mathrm{pH}=6.5, \mathrm{As}=500 \mathrm{rpm}$, and $\mathrm{j}=0.40 \mathrm{~A} / \mathrm{cm}^{2}$.

During the degradation of 4-CP, the hydroxyl radicals can be expected attack to the benzene ring at the ortho-, meta- or para-positions to produce both phenol and 4-chlorocatechol. Here the formation of the phenol and 4-chlorocatechol was observed. The phenol compound is likely converted to hydroquinone. This is in agreement with previous studies related to the reaction pathway of degradation of 4-CP [16]. Meanwhile, the 4-chlorocatechol is likely converted to catechol.

The aromatic compounds (4-CC, CC, HQ, BQ, Ph) and organic acids (MaA, MA, AA, SA, $\mathrm{FuA}, \mathrm{OA}$, and FA) were detected. The concentration profiles of aromatic compounds during the course of degradation of 4-CP are shown in Fig. 5a. This figure depicts the formation of aromatic by-products that began to decrease during electrolysis time. Also it can be seen that 4-CC, BQ, and $\mathrm{CC}$ did not reach total degradation. Meanwhile, in Fig. $5 \mathrm{~b}$ the organic acids, OA and MaA attained their maxima at $30 \mathrm{~min}, \mathrm{FA}$ at $120 \mathrm{~min}, \mathrm{AA}$ at $90 \mathrm{~min}, \mathrm{SC}$ at $60 \mathrm{~min}$, and MA only at the beginning of the electrochemical reaction with low concentration, which is in accord with [16]. The above description suggests a degradation pathway of 4-CP as shown in Fig. 6.

This proposed degradation pathway is useful in explaining the main reactions that occur during degradation of 4-CP and shows all intermediates that appear in the electrolysis process when two BDD electrodes are employed. Moreover, this degradation pathway is more complete than reported in the literature, because in [16] CC, AA, SC, and MA have not been reported, while [35] proposed three degradation paths, including acrylic acid. Furthermore, the presence of by-products at the end of the electrolysis reaction indicates that total mineralization has not been reached under specifies reaction conditions. 


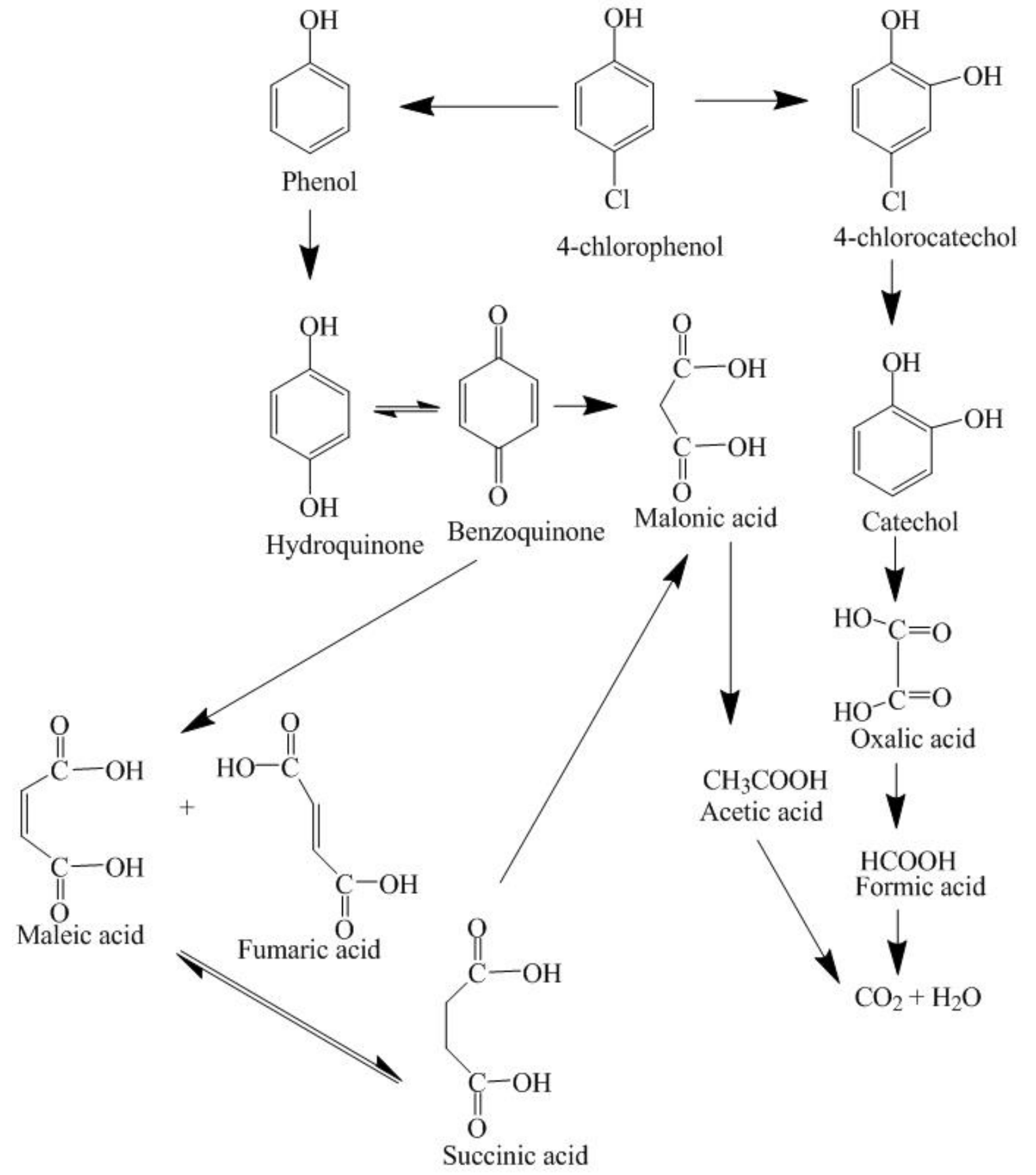

Figure 6. Proposed degradation pathway of $4-\mathrm{CP}$ during the electrochemical process, $[4-\mathrm{CP}]_{0}=500$ $\mathrm{mg} / \mathrm{L}, \mathrm{pH}=6.5, \mathrm{As}=500 \mathrm{rpm}$, and $\mathrm{j}=0.40 \mathrm{~A} / \mathrm{cm}^{2}$.

\subsubsection{4-CP decay}

Figs. 7 and 8 show that BDD electrodes are able to remove 4-CP and concurrently mineralize the wastewater studied in a period of 150 minutes. This suggests that large amounts of $\bullet \mathrm{OH}$ are produced by BDD electrodes and react very fast with all byproducts of the degradation of 4-CP to yield $\mathrm{CO} 2$. 
An apparent first-order rate constant $k$ of $3.527 \times 10^{-4} \mathrm{~s}^{-1}$ was found by fitting the above concentration decay $\left(\mathrm{R}^{2}=0.9402\right)$. In Fig. 7 are plotted the comparison between the experimental data versus data obtained with the pseudo-first kinetic order model, with a high correlation between the two $\left(\mathrm{R}^{2}=0.9799\right)$.

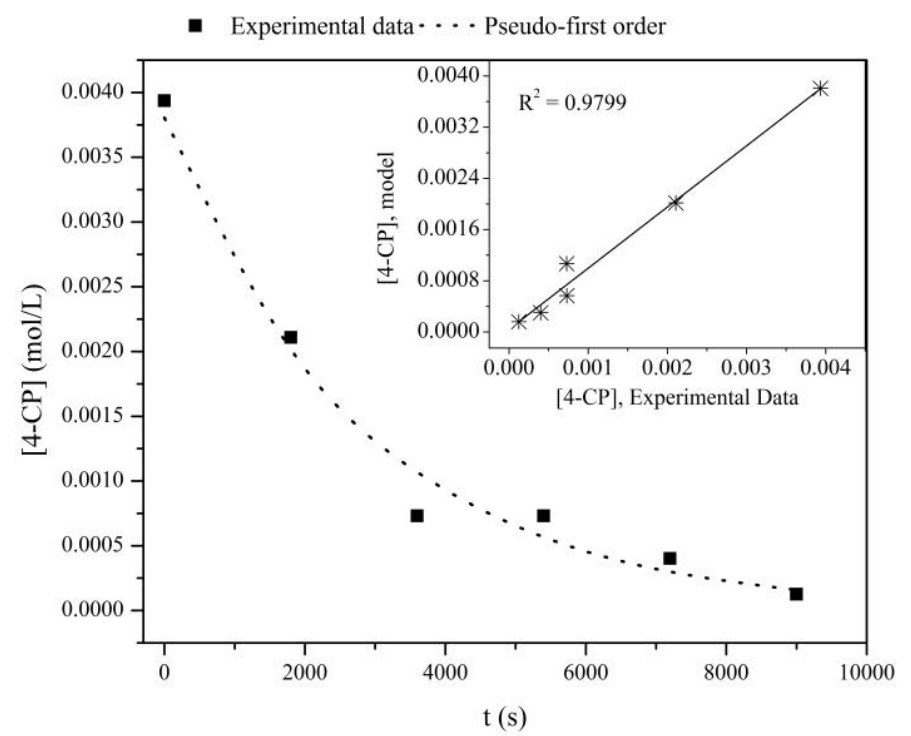

Figure 7. Comparison of the 4-CP decay with electrolysis time under the best electrochemical conditions with the pseudo-first order kinetic model.

\subsubsection{TOC removal}

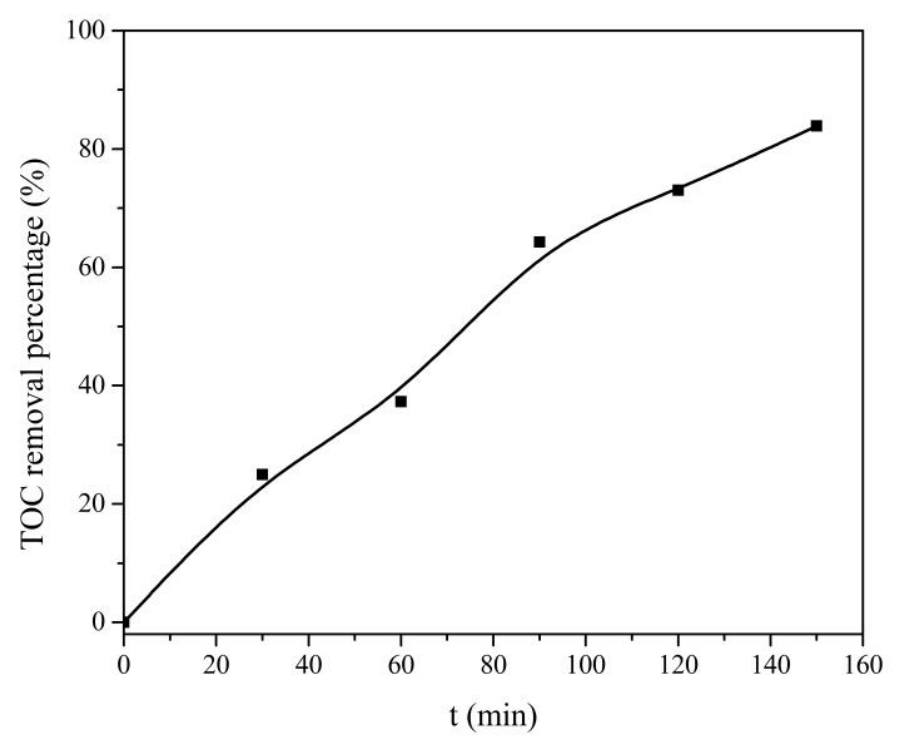

Figure 8. TOC decay under the best experimental conditions $[4-\mathrm{CP}]_{0}=500 \mathrm{mg} / \mathrm{L}, \mathrm{pH}=6.5$, As $=500$ $\mathrm{rpm}$, and $\mathrm{j}=0.40 \mathrm{~A} / \mathrm{cm}^{2}$. 
The TOC removal percentage during electrolysis under the best experimental conditions is displayed in Fig. 8. The TOC removal percentage increased with time, with a removal at $83 \%$ of the maximum TOC achieved at $150 \mathrm{~min}$ of electrolysis time. Because complete TOC removal was not achieved, this indicates that organic compounds had not been completely mineralized and more electrolysis time must be employed.

\subsubsection{Mineralization Current Efficiency}

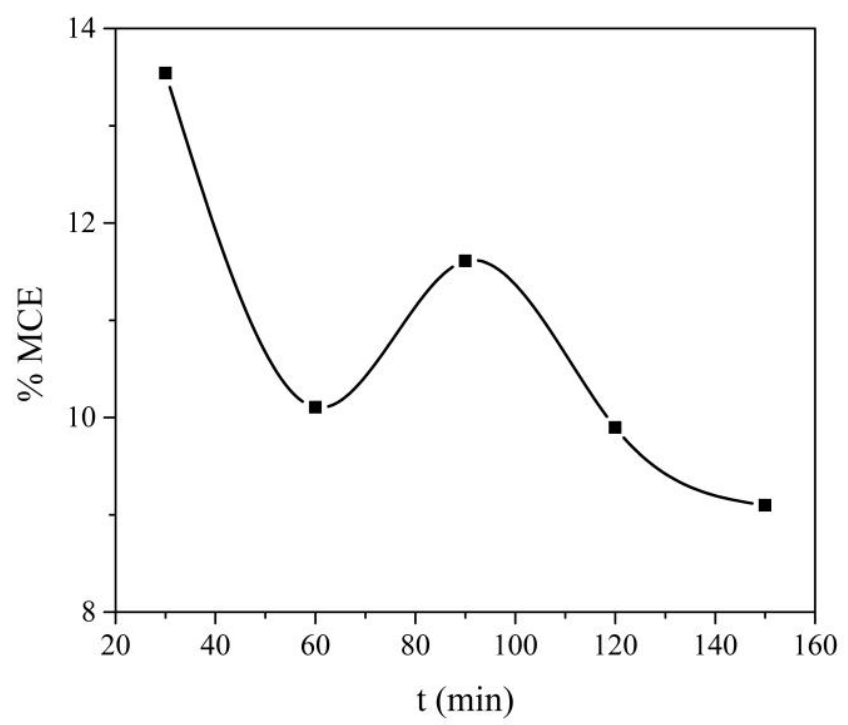

Figure 9. Mineralization current efficiency (MEC), $[4-\mathrm{CP}]_{0}=500 \mathrm{mg} / \mathrm{L}, \mathrm{pH}=6.5, \mathrm{As}=500 \mathrm{rpm}$, and $\mathrm{j}$ $=0.40 \mathrm{~A} / \mathrm{cm}^{2}$.

The MCE values estimated by using Eq. (3) versus time are shown in Fig. 9. The MCE value diminished from $13.5 \%$ to $9.0 \%$ during electrochemical degradation of 4 -CP. This suggests that the current applied is primarily consumed in production of $\bullet \mathrm{OH}$ for the degradation of 4-CP to yields $\mathrm{CO}_{2}$ and by-products, with the latter being slowly removed in the electrolysis process [13]. This may explain the $83 \%$ of TOC removal and lower MCE.

\subsubsection{Energy consumption}

Energy consumption (EC) versus time is depicted in Fig. 10, where the minimum energy consumption is at $30 \mathrm{~min}$ of electrolysis, which coincides with maximum mineralization of pollutant. Additionally, at $150 \mathrm{~min}$ the $\mathrm{EC}$ value was $2.55 \mathrm{~kW} \mathrm{~h} / \mathrm{g} \mathrm{TOC}$, at which point the mineralization percentage and current efficiency were $83 \%$, and $9.0 \%$, respectively. The EC was computed by equation (5). This behavior is shown because there is a diminished organic load in the synthetic solution. Furthermore, the relatively low energy consumption suggests the use of solar panels to provide the required energy and contribute to the sustainability of the process. 


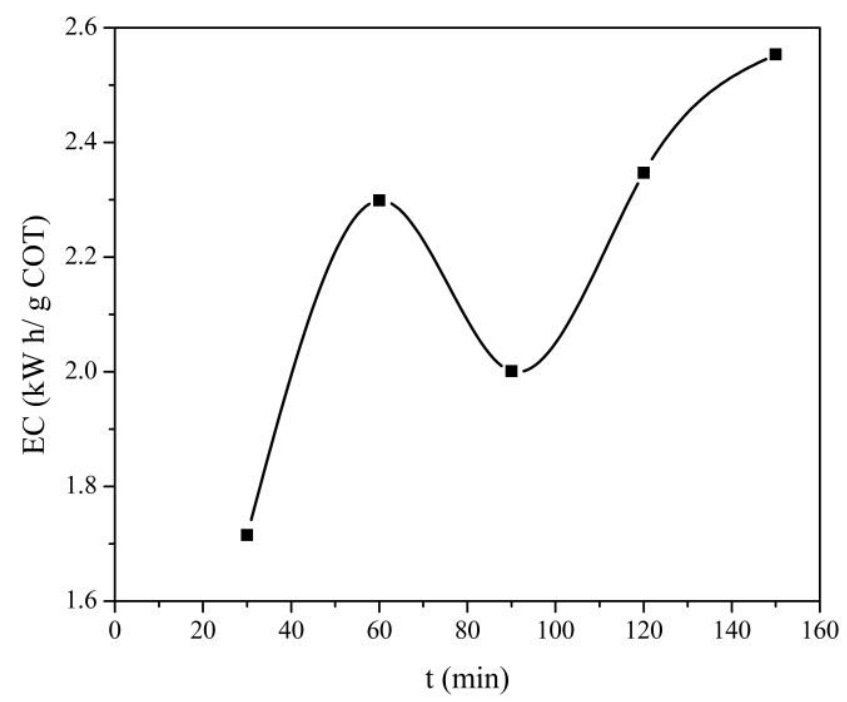

Figure 10. Energy consumption per mass unit of TOC $[4-\mathrm{CP}]_{0}=500 \mathrm{mg} / \mathrm{L}, \mathrm{pH}=6.5$, As $=500 \mathrm{rpm}$, and $\mathrm{j}=0.40 \mathrm{~A} / \mathrm{cm}^{2}$.

Finally, the results in this research about degradation of 4-CP by using BDD electrodes in a batch cell were compared with other studies reported in the literature, in which the degradation of 4-CP was performed with other types of electrodes. Table 1 compares the results of this investigation with the literature. Data presented in this table indicate that degradation of 4-CP is influenced by electrode material type because experiments of degradation of 4-CP at relatively similar electrochemical reaction conditions (except for electrode material type) reach different degradation percentages and mineralization percentages, as shows in [14] and [16]. Moreover, in all compared investigations high degradation percentage were reached except in one report [11], where only $57 \%$ of mineralization was reached after 150 min of electrolysis. Furthermore, in the present work high degradation of 4-CP and mineralization percentages of 4-CP were reached at equal electrolysis time. Additionally, the \% MCE and EC were $9 \%$ and $2.55 \mathrm{kWh} / \mathrm{g}$ TOC, respectively. Based on the results of this study one may conclude that the employed methodology can be applied as an effective treatment system for chlorophenols, and especially for 4-CP.

Table 1. Comparison of electrochemical degradation of 4-CP under different reaction conditions

\begin{tabular}{|c|c|c|c|c|c|c|}
\hline \multirow[b]{2}{*}{ Reaction conditions } & \multicolumn{5}{|c|}{ Main results } & \multirow[b]{2}{*}{ Reference } \\
\hline & $\% \mathrm{TOC}$ & $\% \mathrm{DQO}$ & $\begin{array}{c}\% \\
\text { removal }\end{array}$ & $\% \mathrm{MCE}$ & $\begin{array}{c}\mathrm{EC} \\
(\mathrm{kW} \mathrm{h} / \mathrm{g} \\
\text { TOC })\end{array}$ & \\
\hline $\begin{array}{l}\mathrm{pH}=6, \quad \mathrm{j}=3.5 \\
\mathrm{~mA} / \mathrm{cm}^{2}, \quad[4-\mathrm{CP}]_{0}= \\
100 \mathrm{mg} / \mathrm{L}, \mathrm{V}=1000 \\
\mathrm{~mL}, \quad \text { electrolyte } \\
\mathrm{Na}_{2} \mathrm{SO}_{4}=5 \mathrm{~g} / \mathrm{L} \text {, and } \\
\text { electrode } \beta-\mathrm{PbO}_{2}\end{array}$ & --- & --- & $\begin{array}{c}57.0 \\
(150 \mathrm{~min})\end{array}$ & --- & --- & [11] \\
\hline
\end{tabular}




\begin{tabular}{|c|c|c|c|c|c|c|}
\hline $\begin{array}{l}\mathrm{j}=25 \mathrm{~mA} / \mathrm{cm}^{2}, \mathrm{~V}= \\
1000 \mathrm{~mL}, \quad[4-\mathrm{CP}]_{0}= \\
190 \mathrm{mg} / \mathrm{L}, \text { electrolyte } \\
\mathrm{NaCl}=1.9 \mathrm{~g} / \mathrm{L}, \text { and } \\
\text { electrode } \mathrm{Ti} / \mathrm{RuO}_{2^{-}} \\
\mathrm{IrO}_{2}\end{array}$ & --- & $\begin{array}{c}70.0 \\
(180 \mathrm{~min})\end{array}$ & $\begin{array}{c}100.0 \\
(180 \mathrm{~min})\end{array}$ & --- & --- & [36] \\
\hline $\begin{array}{l}\mathrm{pH}=5.2, \mathrm{j}=222.22 \\
\mathrm{~A} / \mathrm{cm}^{2}, \mathrm{~V}=1000 \mathrm{~mL}, \\
{[4-\mathrm{CP}]_{0}=100 \mathrm{mg} / \mathrm{L},} \\
\text { electrolyte } \mathrm{NaCl}= \\
400 \quad \mathrm{mg} / \mathrm{L} \text { and } \\
\text { electrode } \mathrm{Ti} / \mathrm{RuO} 2\end{array}$ & --- & $\begin{array}{c}96.7 \\
(180 \mathrm{~min})\end{array}$ & $\begin{array}{c}97.2 \\
(180 \mathrm{~min})\end{array}$ & --- & --- & [35] \\
\hline $\begin{array}{l}\mathrm{pH}=6.5, \mathrm{j}=25 \\
\mathrm{~mA} / \mathrm{cm}^{2}, \quad[4-\mathrm{CP}]_{0}= \\
1028.4 \quad \mathrm{mg} / \mathrm{L}, \\
\text { electrolyte } \mathrm{Na}_{2} \mathrm{SO}_{4}, \\
\text { and electrodes }\left(\mathrm{PbO}_{2}\right. \\
\text { and } \mathrm{PbO})\end{array}$ & --- & --- & $\begin{array}{c}87.3 \\
96.2 \\
(120 \mathrm{~min})\end{array}$ & --- & --- & [14] \\
\hline $\begin{array}{l}\mathrm{j}=30 \mathrm{~mA} / \mathrm{cm}^{2}, \quad[4- \\
\mathrm{CP}]_{0}=50 \mathrm{mg} / \mathrm{L}, \mathrm{V}= \\
200 \mathrm{~mL}, \text { electrolyte } \\
\mathrm{Na}_{2} \mathrm{SO}_{4} 0.05 \mathrm{M}, \mathrm{T}= \\
333 \mathrm{~K}, \text { electrodes } \\
\left(\mathrm{PbO}_{2},\right. \\
\mathrm{CNT}_{-} \mathrm{PbO}_{2}, \mathrm{LAS}- \\
\mathrm{PbO}_{2}, \text { and LAS-CNT- } \\
\left.\mathrm{PbO}_{2}\right)\end{array}$ & $\begin{array}{c}56.6 \\
73.7 \\
74.1 \\
88.8 \\
\text { (180 min) }\end{array}$ & --- & $\begin{array}{c}79.5 \\
84.9 \\
85.6 \\
99.5 \\
(120 \mathrm{~min})\end{array}$ & --- & --- & [16] \\
\hline $\begin{array}{l}\mathrm{pH}=6.5, \mathrm{j}=0.40 \\
\mathrm{~A} / \mathrm{cm}^{2},[4-\mathrm{CP}]_{0}=500 \\
\mathrm{mg} / \mathrm{L}, \mathrm{V}=400 \mathrm{~mL}, \\
\text { electrolyte } \mathrm{Na}_{2} \mathrm{SO}_{4} \\
0.1 \mathrm{M}, \mathrm{T}=298.15 \mathrm{~K}, \\
\text { and electrode BDD }\end{array}$ & $\begin{array}{c}83.0 \\
(150 \mathrm{~min})\end{array}$ & --- & $\begin{array}{c}96.0 \\
(150 \mathrm{~min})\end{array}$ & $\begin{array}{c}9.0 \\
(150 \mathrm{~min})\end{array}$ & $\begin{array}{c}2.55 \\
(150 \mathrm{~min})\end{array}$ & This work \\
\hline
\end{tabular}

\section{CONCLUSIONS}

The degradation of 4-CP was successfully carried out by electrochemical reactions in a batch cell without division equipped with BDD electrodes. Different experimental conditions were tested, including current density (from 0.25 to $0.4 \mathrm{~A} / \mathrm{cm}^{2}$ ), initial solution $\mathrm{pH}(2.6,6.5$ and 12), stirring speed (400, 500 and $600 \mathrm{rpm}$ ), and initial 4-CP concentration (300, 500 and $700 \mathrm{mg} / \mathrm{L})$. According to the experimental results, the best conditions were found to be $0.40 \mathrm{~A} / \mathrm{cm}^{2}, \mathrm{pH}$ of $6.5,500 \mathrm{rpm}$ and 500 $\mathrm{mg} / \mathrm{L}$, which yielded a mineralization percentage of $83 \%$ of TOC elimination. The $\mathrm{pH}$ of the solution, stirring speed and the initial concentration did not have an important effect on the electrochemical degradation, so $\mathrm{pH}$ adjustment is unnecessary to eliminate a phenolic compound (e.g., 4-CP) in synthetic solution through the methodology employed in the present investigation. From UHPLC analysis under the best conditions of electrolysis reaction, by-product compounds were established and 
a reaction pathway of 4-CP throughout the process was proposed. Degradation of 4-CP follows pseudo-first-order kinetics, and the model has high correlation with the experimental data $\left(\mathrm{R}^{2}=\right.$ 0.9799). The results of this study support the use of DBB electrodes in electrochemical processes as a very promising method to remove persistent organics (e.g., chlorophenols) in wastewater treatment.

\section{ACKNOWLEDGEMENTS}

This work has been supported by PRODEP (projects DSA/103.5/14/11350, 2014; CUP: 2IE1503, DSA/103.5/16/10242; CUP: 2II1605, 2016) and CONACYT (project 269093).

\section{References}

1. P. Wongwisate, S. Chavadej, E. Gulari, T. Sreethawong, P. Rangsunvigit, Desalination, 272 (2011) 154.

2. H. Wang, J. Wang, Appl. Cat. B: Environ., 77 (2007) 58.

3. G. Santana-Martínez, G. Roa-Morales, E. Martin del Campo, R. Romero, B.A. Frontana-Uribe, R. Natividad, Electrochim. Acta., 195 (2016) 246.

4. E. Martin del Campo, R. Romero, G. Roa, E. Peralta-Reyes, J. Espino-Valencia, R. Natividad, Fuel, 138 (2014) 149.

5. P.T. Anastas, J.B. Zimmerman, Environ. Sci. Technol., 37 (2003) 94A.

6. I. Sirés, E. Brillas, Environ. Int., 40 (2012) 212.

7. C. Comninellis, G. Chen, SpringerLink, Electrochemistry for the environment, Springer, New York, 2010.

8. M.O. Azzam, M. Al-Tarazi, Y. Tahboub, J. Hazard. Mater., 75 (2000) 99.

9. M.A. Rodrigo, P.A. Michaud, I. Duo, M. Panizza, G. Cerisola, C. Comninellis, J. Electrochem. Soc., 148 (2001) D60.

10. L. Gherardini, P.A. Michaud, M. Panizza, C. Comninellis, N. Vatistas, J. Electrochem. Soc., 148 (2001) D78.

11. C. Yan-qing, W. Zu-cheng, Y. Qian, T. Tian-en, J. Zhejiang University-SCIENCE A, 5 (2004) 180.

12. Y.H. Wang, K.Y. Chan, X.Y. Li, S.K. So, Chemosphere, 65 (2006) 1087.

13. R.D. Coteiro, A.R. De Andrade, J. Appl. Electrochem, 37 (2007) 691.

14. J. Cao, H. Zhao, F. Cao, J. Zhang, C. Cao, Electrochim. Acta, 54 (2009) 2595.

15. J.-L. Chen, G.-C. Chiou, C.-C. Wu, Desalination, 264 (2010) 92.

16. X. Duan, F. Ma, Z. Yuan, L. Chang, X. Jin, Electrochim. Acta, 76 (2012) 333.

17. X. Duan, L. Tian, W. Liu, L. Chang, Electrochim. Acta, 94 (2013) 192.

18. D. Hernández-Fuerte, J. Mex. Chem. Soc., 58(3) (2014) 339.

19. L.S. Andrade, T.T. Tasso, D.L. da Silva, R.C. Rocha-Filho, N. Bocchi, S.R. Biaggio, Electrochim. Acta, 54 (2009) 2024.

20. M. Panizza, G. Cerisola, Chem. Rev., 109 (2009) 6541

21. C.A. Martínez-Huitle, E. Brillas, Appl. Cat. B: Environ., 87 (2009) 105.

22. O. García, E. Isarain-Chávez, A. El-Ghenymy, E. Brillas, J.M. Peralta-Hernández, J. Electroanal. Chem., 728 (2014) 1.

23. E. Peralta, R. Natividad, G. Roa, R. Marin, R. Romero, T. Pavon, Sustain. Environ. Res., 23 (2013) 259.

24. K. Cruz-González, O. Torres-Lopez, A.M. García-León, E. Brillas, A. Hernández-Ramírez, J.M. Peralta-Hernández, Desalination, 286 (2012) 63.

25. E. Isarain-chávez, C. De La Rosa, C.A. Martínez-huitle, J.M. Peralta-hernández, Int. j. Electrochem. Sci., 8 (2013) 3084

26. J.A. Barrios, E. Becerril, C. De León, C. Barrera-Díaz, B. Jiménez, Fuel, 149 (2015) 26.

27. P.J. Espinoza-Montero, R. Vasquez-Medrano, J.G. Ibanez, B.A. Frontana-Uribe, J. Electrochem. 
Soc., 160 (2013) G3171.

28. E. Brillas, S. Garcia-Segura, M. Skoumal, C. Arias, Chemosphere, 79 (2010) 605.

29. E. Guinea, C. Arias, P.L. Cabot, J.A. Garrido, R.M. Rodríguez, F. Centellas, E. Brillas, Water Res., 42 (2008) 499.

30. M. Skoumal, C. Arias, P.L. Cabot, F. Centellas, J.A. Garrido, R.M. Rodríguez, E. Brillas, Chemosphere, 71 (2008) 1718.

31. E. Brillas, I. Sirés, M.A. Oturan, Chem. Rev., 109 (2009) 6570.

32. A.S. Fajardo, H.F. Seca, R.C. Martins, V.N. Corceiro, I.F. Freitas, M.E. Quinta-Ferreira, R.M. Quinta-Ferreira, J. Electroanal. Chem., 785 (2017) 180.

33. C.R. Wang, J. Wang, X.G. Ma, H. Li, S.Z. Zhang, J. Chem., 2015 (2015) 1.

34. J.L. Nava, I. Sirés, E. Brillas, Environ. Sci. and Pollut. Res., 21 (2014) 8485.

35. R. Chauhan, V.C. Srivastava, A.D. Hiwarkar, J. Taiwan Inst. Chem. Eng., 69 (2016) 106.

36. J. De Coster, W. Vanherck, L. Appels, R. Dewil, J. Environ. Manage., 190 (2017) 61

(C) 2018 The Authors. Published by ESG (www.electrochemsci.org). This article is an open access article distributed under the terms and conditions of the Creative Commons Attribution license (http://creativecommons.org/licenses/by/4.0/). 